\title{
THE READABILTY OF READING MATERIALS IN ENGLISH TEXTBOOK FOR THE ELEVENTH GRADE STUDENTS OF SMK NEGERI 1 BERINGIN
}

\author{
*Theo Kismarianto \\ **Dra. Masitowarni Siregar, M.Ed \\ ** Yeni Erlita, S.Pd., M.Hum
}

\begin{abstract}
Kismarianto, Theo, Registration Number: 2123321083. The Readability of Reading Materials in English Textbook for the Eleventh Grade Students of SMK Negeri 1 Beringin. A Thesis. English Educational Program, State University of Medan, 2018.

This study focused on the readability of reading materials in English textbook for grade XI students of SMK Negeri 1 Beringin. This study attempted to find out the English reading materials appropriateness in terms of the readability level for the target students. This study was categorized as descriptive quantitative research. The source of the data were the reading materials from English in Professional Job Situations textbook published by Grafindo Media Pratama which was designed under guidance of Kurikulum Tingkat Satuan Pendisdikan (KTSP). The Dale and Chall original formula was used to analyze the data from the textbook. The findings of the study showed that most of the reading materials in English in Professional Job Situations textbook were only appropriate for the $13-15^{\text {th }}$ grade (college) and were considered too hard for the eleventh grade students.
\end{abstract}

Keywords: Readability, The Dale and Chall Original Formula, Readability Formula, English Textbooks for Eleventh Grade Students.

\footnotetext{
*Graduate Status

**Lecturer Status
} 


\section{INTRODUCTION}

\section{Background of the Study}

Every school uses textbooks as the media in teaching and learning process. Especially for learning English, textbook has been a dominant learning source apart from other learning sources.

In Indonesia, curriculum governs the designing of textbook. One of the curriculum is Kurikulum Tingkat Satuan Pendidikan (KTSP). Many different publishers design a textbook based on the curriculum. This means the topics are the same, but since the publishers are different, the difficulty of the materials can also different, especially in term of the reading material which is the focus of this study.

Teachers should be able to select a textbook with suitable difficulty for the reading materials. Regarding the difficulty of a reading material, readability formulas can be used to measure a reading material.

According to Anderson \& Davison (1986, p.3) and Dubay (2004, p.1), readability of a reading material can be measured by considering various factors, some of them are words difficulty and sentence length which have been considered as the direct cause of difficulty in comprehension.

Appropriate readability of a reading material will motivate the students to enjoy reading. In result, it will be easier for the students to comprehend the reading materials and surely, it will help their learning process. In contrary, inappropriate reading materials will make the students bored and frustrated, furthermore if the students are forced to read a reading material which is too difficult for them, the 
students will not only fall behind in their education but will also have a miserable time (Flesch, 1949, p. 147).

From the statements above, it can be said that readability plays a critical role in a learning process. Regarding the readability, there have been some studies about the readability of reading materials in various schools which showed varying results. Owu-Ewie (2014, p. 35) conducted a study to find out the readability of 48 comprehension passages of English texbooks in Ghana and found out that most of the passages were too hard to read and comprehend for the readers.

Another study by Browne (1996, p. 1), who conducted a study about Japanese EFL Reading Texts, he found out that the difficulty of the Japanese EFL Reading texts varied from low to high difficulty. Another study conducted in Indonesia by Mulyadi (2015, p. 149) who studied the readability of reading materials used by university level students and it was found out that some of the texts were too difficult for the students.

Those three studies indicate that not all reading materials are readable for the students. Therefore, it is necessary to measure the readability of a reading material. In measuring the readability of a reading material, there are some readability tests available. The readability tests are readability formulas, cloze test, checklist, scales, and text leveling. The popular one is readability formula which measures the readability of a text by using the vocabulary difficulty and length of text as factors to measure. Readability formulas are objective in giving prediction of a text difficulty, while no other tests provide the same objectivity like the readability formulas do 
(Dubay, 2004, p. 3). Also, readability formulas are valid for a broad spectrum of English readers that includes non-native as well as native readers. In other words, they work quite well to predict the relative EFL/ESL difficulty of English academic texts (Greenfield, 2004, p. 11).

Therefore, this study was focused on the use of readability formula to analyze the readability of the reading texts from the English textbooks used by eleventh grade students in SMK Negeri 1 Beringin.

\section{REVIEW OF LITERATURE}

\section{Reading}

Reading is an activity in which readers respond to and make sense of a text being read which is connected to their prior knowledge (Spratt et al., 2005, p. 21). The activity is done by the readers as they want to get information and knowledge from the text. In this process, the readers try to connect what they read in the form of written language to what they have already known about the text. Making sense of a text is done by understanding meaning of words, sentences, and even a text.

Reading may also be defined as a process in which readers learn something from what they read and involve it in academic context as a part of education (Grabe, 2009, p. 5). Learning happens when there is a change in mind from an unknown thing to the known one. As reading is included in learning, the 
readers try to grasp the texts being read by interpreting, synthesizing, evaluating, and selecting the important information.

\section{Textbook}

Georgescu and Bernard (2007, p. 12) define, textbook is a type of 'text', defined as 'materials in any publishable form (print, digital, multimedia) that support teaching and learning', but they are comprehensive in scope and thus more authoritative.

Seguin (1989, p. 18) also adds that textbook is an educational text which propose a structure, and an order and a progression in the teaching-learning process. Further definition, textbook is a compilation of texts and tasks which are classified by an author as a good material for teaching and learning a foreign language which also defines a learning process (Fenner, 2000, p. 78).

From those definitions, it can be concluded that a text book is a structured texts and tasks which are used to support teaching and learning process.

\section{Readability}

\section{a. Definition of Readability}

Dubay (2004, p. 3) defines readability as what makes some texts are easier to read than others. Brown et al (2012, p. 1) state that readability is a concept that describes the degree to which a text is easy or difficult to read. Asem (2013, p. 7), furthermore suggests that readability is the ease with which we read and understand a particular written text. Oakland and lane $(2004$, p. 9) then add that readability is the ease with which a reader can read and understand text. 
From the definitions, it can be concluded that readability is the ease which a reader can read a particular text which varies with a certain grading.

\section{b. The Dale and Chall Readability Formula}

There are hundreds of readability formulas. This research used The Dale and Chall Original Readability Formula (1948) which at that era considered as the most reliable of all (Dubay, 2006, p. 61). This formula was developed for adults and children above the 4th grade. The variables used in this formula is sentence-length variable plus a percentage of hard words-words not found on the Dale-Chall long list of 3,000 easy words (Dubay, 2004, p. 23).

The steps in implementing the formula (Dubay, 2004, p. 23) are as follow:

- Select 100-word samples throughout the text (for books, every tenth page is recommended).

- Compute the average sentence length in words.

- Compute the percentage of words outside the Dale list of 3,000 words.

- Compute this equation: Score $=.1579 \mathrm{PDW}+.0496 \mathrm{ASL}+3.6365$

Where:

Score $=$ Reading grade of a reader who can answer one-half of the test questions on a passage.

PDW = Percentage of Difficult Words (words not on the Dale Chall word list)

ASL = Average Sentence Length in words. 
Dale and Chall also published the chart for correcting the grade-level scores at the higher grades.

\begin{tabular}{lc}
\hline \multicolumn{1}{c}{ Formula Score } & Corrected Grade Levels \\
\hline 4.9 and below & Grade 4 and below \\
\hline 5.0 to 5.9 & Grades 5-6 \\
\hline 6.0 to 6.9 & Grades $7-8$ \\
\hline 7.0 to 7.9 & Grades 9-10 \\
\hline 8.0 to 8.9 & Grades 11-12 \\
\hline 9.0 to 9.9 & Grades 13-15 (college) \\
\hline 10 and above & Grades 16 and above (college graduate) \\
\hline Table 2.1. Dale-Chall Grade Correction Chart (Dubay, 2006, p. 81) \\
\\
\end{tabular}

Methodology

This research applied descriptive quantitative method to analyze the readability of reading texts in English textbooks used by the eleventh grade students in SMK Negeri 1 Beringin. This study described the readability of the textbook by using The Dale and Chall Original Readability Formula.

The data of this research were the reading texts from English in Professional Job Situations textbook published by Grafindo Media Pratama. The textbook consists of 20 reading texts. There were two text selected from each genre which total to 8 reading texts as the sample of this research. 
The data then were analyzed using The Dale and Chall Original Formula with these following steps:

1. Selecting two texts from each genre.

2. Computing the average sentence length in words.

3. Computing the percentage of words outside the Dale list of 3,000 words.

4. Computing this equation: Score $=0.1579 \mathrm{PDW}+0.0496 \mathrm{ASL}+3.6365$

Where:

Score $\quad=$ Reading grade of a reader who can answer one-half of the test questions on a passage.

PDW $=$ Percentage of Difficult Words (words not on the Dale Chall word list)

ASL = Average Sentence Length in words.

Findings

The analysis revealed the readability of reading texts in the textbooks by using the Dale and Chall readability formula. After analyzing all the texts, the findings of the study could be seen below:

- Reading texts from English in Professional Job Situations

1. The text entitled Outdoor Activities which was an analytical exposition text had 9.63 of readability score. Based on the Dale and Chall formula the text was appropriate for the $13-15^{\text {th }}$ grade level. The text was predicted to be too hard for the eleventh grade. The average sentence length was 
24.67 and there were 67 words that were not found in the Dale list of 3,000 words.

2. The text entitled Queuing Systems which was an analytical exposition text had 10.26 of readability score. Based on the Dale and Chall formula the text was appropriate for the $16^{\text {th }}$ grade level. The text was predicted to be too hard for the eleventh grade. The average sentence length was 15.67 and there were 87 words that were not found in the Dale list of 3,000 words.

3. The Text entitled Career Break Travel in Page 60 which was a descriptive text had 8.35 of readability score. Based on the Dale and Chall formula the text was appropriate for the $11-12^{\text {th }}$ grade level. The text was predicted to be appropriate for the eleventh grade. The average sentence length was 16.68 and there were only 78 words that were not found in the Dale list of 3,000 words.

4. The text entitled Television Reporter which was a descriptive text had 7.80 of readability score. Based on the Dale and Chall formula the text was appropriate for the $9-10^{\text {th }}$ grade level. The text was predicted to be too easy for the eleventh grade. The average sentence length was 14.29 and there were 97 words that were not found in the Dale list of 3,000 words.

5. The text entitled How to Mix Concrete which was a procedure text had 6.55 of readability score. Based on the Dale and Chall formula the text was appropriate for the $7-8^{\text {th }}$ grade level. The text was predicted to be too 
easy for the eleventh grade. The average sentence length was 11.57 and there were 12 words that were not found in the Dale list of 3,000 words.

6. The text entitled How to Use Stone Mortar and Pestle which was a procedure text had 9.00 of readability score. Based on the Dale and Chall formula the text was appropriate for the $13-15^{\text {th }}$ grade level. The text was predicted to be too hard for the eleventh grade. The average sentence length was 23.71 and there were 44 words that were not found in the Dale list of 3,000 words.

7. The text entitled Alexander Graham Bell which was a report text had 9.69 of readability score. Based on the Dale and Chall formula the text was appropriate for the $13-15^{\text {th }}$ grade level. The text was predicted to be too hard for the eleventh grade. The average sentence length was 22.33 and there were 84 words that were not found in the Dale list of 3,000 words.

8. The text entitled Steve Job which was a report text had 9.67 readability score. Based on the Dale and Chall formula the text was appropriate for the $13-15^{\text {th }}$ grade level. The text was predicted to be too hard for the eleventh grade. The average sentence length was 15.52 and there were 119 words that were not found in the Dale list of 3,000 words.

\section{CONCLUSION AND SUGGESTIONS}

\section{Conclusion}


This study was conducted to describe out the readability of the English reading texts which consist of analytical exposition, descriptive, procedure and report texts in English in Professional Job Situation textbook for the eleventh grade students in SMK Negeri 1 Beringin by using The Dale and Chall Original Formula. The readability of the eight representative texts from each genre in English in Professional Job Situation textbook indicates that the texts were considered too hard and not appropriate for the eleventh grade students since most of the texts sample is predicted for $13-15^{\text {th }}$ grade level students (college).

\section{Suggestion}

The following are the suggestion for English teachers, researchers of textbooks and other researchers:

\section{For English Teachers}

It is recommended for English teachers to understand and to know the readability of the reading materials given to their students. Teacher should find reading materials which are appropriate for the students. Appropriate reading materials can help the students to improve their reading comprehension.

\section{For Researchers of Textbooks}

The researchers of textbook should give more concern about the readability of the reading materials in the textbooks that they research. They should match the readability of the reading materials to the target students. It is better if the researcher can provide information about the readability of the reading texts in the textbook. 


\section{For Other Researchers}

There are many other textbooks offered by other publishers and also there are other types of readability tests and other readability formulas. The other researchers can use them as the subject of the research and type of test to implement in the research. The researcher hopes that this research can give more information for further research.

\section{REFERENCES}

Anderson, R. C. \& Davidson, A. (1986). Conceptual and Empirical Bases of Readability Formulas. Center for the Study of Reading, 1(2), 1-63.

Asem, B. (2013). Evaluation of Textual Readability - An Analysis of Its Varying Approaches. International Journal of Research in Humanities, Arts and Literature, 1(4), 7-12.

Brown, Janssen \& Trace. (2012). A Preliminary Study of Cloze Procedure as a Tool for Estimating English Readability for Russian Student. Second Language Studies, 31(1), 1-22.

Browne, M. (1996). Japanese EFL Reading Texts: How Readable Are They? Working Papers in Applied Linguistics, 8, 1-12.

Dubay, W. H. (2004). The Principles of Readability. California: Impact Information.

Dubay, W. H. (2006). The Classic Readability Studies. Costa Mesa: Impact Information.

Fenner, A. B. \& Newby, D. (2000). Approaches to Materials Design in European Textbooks: Implementing Principles of Authenticity, Learner Autonomy, Cultural Awareness. Austria: European Centre for Modern Languages

Flesch, R. (1949). The Art of Readable Writing. New York: Harper \& Row. 
Georgescu, D. \& Bernard, J. (2007). Thinking and Building Peace Through Innovative Textbook Design. France: United Nations Educational, Scientific, and Cultural Organization.

Grabe, W. (2009). Reading in a second language: Moving from theory to practice. New York: Cambridge University Press.

Greenfield, J. (2004). Readability Formulas for EFL. JALT Journal. 26(1). 5-24.

Mulyadi. (2015). Tingkat Keterbacaan Reading Materials Dalam Mata Kuliah Telaah Teks Bahasa Inggris Stain Pemekasan. Nuansa. 2 (1). 136-151.

Owu-Ewie, C. (2014). Readability Of Comprehension Passages In Junior High School (Jhs) English Textbooks In Ghana. Ghana Journal of Linguistics. 3 (2), 35-68.

Seguin, R. (1989). The Elaboration of School Textbooks Methodological Guide. France: United Nations Educational, Scientific, and Cultural Organization

Spratt, Mary et al. 2005.The TKT Course. Cambridge: Cambridge University Press. 